\title{
Which Jihadists Group Ambushed US Marines in Tongo - Tongo Niger
}

\author{
LDavid Otto* \\ Director TGS \& CEO SISO R.A.P, UK
}

Submission: October 31, 2017; Published: November 13, 2017

*Corresponding author: David Otto, Director TGS \& CEO SISO R.A.P, Counter Terrorism \& Organised Crime Expert, MSc Counter Terrorism \& Organised Crime, BA (Hons) Law and Criminology, Certified Master Anti-terrorism Specialist (CMAS), L2 Counter Terrorism \& Safeguarding Trainer London, Email: davidotto@tgsintconsultant.com

\section{Opinion}

The fallout in Washington after the ambush in Niger that resulted in the deaths of four Green Berets, four Nigerien forces and several wounded during the October 4th incident has morphed from shock and confusion regarding the incident to becoming a full-fledged media circus regarding who knew about the US troops being in the region and under what circumstances they were deployed in such a volatile region that has a combination of pro and competing AL-Qaeda and ISIL factions. What is the National Security threat that warrants a presence of 800 United States troops in the Sahel? The answer may fall back to a decision made during the Bush (43) Administration.

In the days and weeks after 9/11, Congress passed Public Law 107-40 authorizing the use of force against those the President determined to have planned, authorized, committed or aided the attacks launched against the United States, those who harbored such people and their affiliated organizations. The objective was to prevent any further acts of terrorism directed against the United States by such persons, organizations or nations.

\section{How does the AUMF apply to Niger?}

Consider two events in the Maghreb over the last few decades. First, the Algerian Civil War of 1992. This violent event erupted when the Algerian Military saw fit to cancel a run of elections for Parliament. That decision resulted to violence between Islamic Fundamentalists and Secular Algerians. The Islamic Salvation Front was poised to win power after these polls. After that the carnage led to many factions splitting from previous groups and charting their own course in the North Africa region. During the darkest days of the conflict one powerful Islamist group emerged.

The GPSC (Salafist Group for Preaching and Combat). It first gained prominence in 1998 by splitting away from a previous group that it severed ties with. The GPSC is today notoriously referred to as AQIM (Al-Qaeda in the Islamic Maghreb) and it has spread its tentacles southward into the Sahel splitting into various factions like Al mourabitoum for tactical purposes. Virtually unchallenged for more than two decades, these different jihadists groups are now influencing events in Mali and regional states like Niger since 2012 .

The second event is the execution of the Libya former leader Muhammar Qadaffi and the subsequent collapse of Libya into a sustained period of Civil War and the emergence of many criminal and Salafist Jihadist groups backed by both Al-Qaeda and ISIL core; The chaos that ensued resulted into;

a) The outflow of weapons from Libya into the region

b) The ability for fighters to move through the region with ease

c) The Migrant Crisis that has affected Europe

The events of 2011 set into motion the current crisis in Mali, Burkina- Faso, Niger and the region in general over the last couple of years. The leadership vacuum in Libya has had a ripple effect to the current rising instability in the Sahel and there are no signs of better days ahead.

\section{US - French Response}

To manage the growing instability in the Sahel, the French set up a reaction force known as Operation Barkhane with its main base in N'Djamena - Chad. This operation has been underway since 2014. Contrast that to the TSCTI (Trans Saharan Counterterrorism Initiative) which the United States has had in operation since 2006. Under the banner of the 'Global War on Terror', it is expected that effective response can only be achieved when there is collaboration between both countries, in coordination with local national forces. The deadly event of 4th October questions the effectiveness of intelligence sharing and response collaboration and coordination between US, French and local Nigerien forces. It equally raises the question of transparency, interest and trust by all parties involved. 
There is no doubt that there exists a certain level of collaboration between AFRICOM (US African Command) and the French in the Sahel in terms of sharing Intelligence but same cannot be said to apply with local forces who are mostly at the forefront on ground but undermined due to trust issues. Even between the US and the French, the level of timely information dissemination is very murky. This level of suspicion based on long term interest, lack of trust with local forces and wanting to be 'the one who solved the problem' can have a deadly outcome as seen in the recent ambush.

\section{Change is permanent:}

The AUMF currently being used since 2001 needs a serious review. Local forces do not have the same level of ability and capability like their foreign counterparts. They do however have local experience and understand the backyard culture. In an asymmetric warfare such as the one in the Sahel, 'Culture eats strategy for breakfast, lunch and super'. Local forces should not be undermined in the intelligence sharing and coordination process. This must follow a training process based on 'all that we know, not all that we want you to know'. Without a timely and transparent intelligence sharing between all parties involved both at strategic, planning and operational levels, there will be permanent damage to lives of brave men and women on the frontline.

\section{Which Jihadist Group Killed the US-Nigerien Forces?}

The Jihadist Movement in the Sahel has split into factions that support either Al-Qaeda or the Islamic State on the ideological level. There exist AQIM with factions that now include 'The Islamic State in the Greater Sahara' (ISGS) under the leadership of Abu Walid Al Sahrawi, Al Mourabitoum under Mokhtar Belmokhtar (No evidence Belmokhtar has been killed) and the Islamic State of West Africa Province (ISWAP) under Abu Musab Al Barnawi sharing notes conveniently with Ansaru under Mamam Nur. Not to forget well established organized criminal groups in the region that form the crime-terror nexus network.

The reality on ground is a smooth co-existence of these opposing factions. From time to time they are known to coordinate through intelligence sharing, planning and preparation against common enemy targets particularly high profile western targets. Hence Jihadist long standing success in launching attacks against different Western and national Interests in the Region has remained impossible to pin down.

Discerning Intelligence matters regarding which group are behind the recent attack may lead to the proper response but when these groups do collaborate, the monopoly of claiming responsibility becomes impossible even by the group that pulled the killer trigger.

\section{US -French Response.}

Having the French Air Force scramble their jets over the surface of the attack zone hours after the attack and evacuate the US Casualties highlights the strong bond between the French and American Armed Forces in the region and beyond. However, there is a MAGTF (Marine Air and Ground Task Force) that is designed for use in Africa and based in Spain but the response time in remote areas like Niger are from the quick one hour practiced in the likes of Iraq, Syria and Afghanistan.

\section{Why weren't the Green Berets able to get help in time?}

Eventually, help arrived specifically from the French, but too little too late against 'invincible' locally imbedded adversaries that had time to plan and prepare and perhaps understood the routine of the joint patrol and the time it takes for response to arrive, plus the capacity of that response. It is equally possible that the one-hour alleged delay in requesting for backup assistance was because the joint US-Nigerien patrol was confident it had the situation under control. Due to the nature of the terrain, it was impossible to estimate how many fighters the joint US - Nigerien patrol was up against. Putting these factors into account and the experience of the joint patrol albeit the surprise nature of the attack, it is likely that the Jihadists were more than the official estimate of 50 fighters. Even with US manned drones circulating above, that figure was too quick to arrive at.

\section{Conclusion}

There has been controversy within the US public over having a US Military Footprint in Africa. If this ambush is not an excuse for the US to push for 'shoot and ask questions later' tactic in the region then it exposes the downside of not only deploying in remote and fragile regions in Africa, but not deploying enough footprint to respond to the threats. Special Forces are easy to use just like UAVs but they are suited for reaction rather than medium to long term deployment. In such circumstances of asymmetric conflicts, a larger capacity is needed but very few inside the beltway will give Pentagon the proper tools to adequately fulfill the requests of the Commander in Chief. The only way to close the Counter special force shortage gap is a long-term strategy to train and equip local forces to the standard that is required to effectively tackle jihadists in the region. The continuous presence of US forces in Africa has become a massive concern to voters and relatives of fallen soldiers just as much as the deployment size of Special Forces in Africa. The government must reconsider its strategy on deploying forces in Africa if the project is long term.

The routine mission to the North of Niamey, close to the village of Tongo Tongo was categorized as 'low risk'. In this volatile region of the Sahel, a long period of 'low risk' usually means high vulnerability. The joint Nigerien - US patrol team may have become consistently consistent for jihadist sleeper cells in the region to plan and launch a surprise strike just when it was least expected. The nature of the attack seems a cross coordination between different Jihadists groups in the Sahel region requiring understanding of the jihadist network in the region to unmask 'the group that pulled the trigger' on US \& Nigerien forces on Oct $4^{\text {th }}, 2017$. 
This work is licensed under Creative

Commons Attribution 4.0 License

DOI: 10.19080/JFSCI.2017.06.555681

\section{Your next submission with Juniper Publishers} will reach you the below assets

- Quality Editorial service

- Swift Peer Review

- Reprints availability

- E-prints Service

- Manuscript Podcast for convenient understanding

- Global attainment for your research

- Manuscript accessibility in different formats

( Pdf, E-pub, Full Text, Audio)

- Unceasing customer service

Track the below URL for one-step submission https://juniperpublishers.com/online-submission. 